\title{
Epidemiological analysis of Schistosomiasis Mansoni in Brazilian regions
}

\author{
Análise epidemiológica da Esquistossomose Mansônica nas regiões do Brasil \\ Análisis epidemiológico de la Esquistosomiasis Mansónica en regiones de Brasil
}

Received: 01/10/2022 | Reviewed: 01/18/2022 | Accept: 01/25/2022 | Published: 01/26/2022

Tallis Martins Cafieiro

ORCID: https://orcid.org/0000-0003-3917-2769 Universidade Luterana do Brasil, Brasil

E-mail: talcafieiro@gmail.com

Nataly Salvatierra Sodré

ORCID: https://orcid.org/0000-0003-2683-8883 Universidade Luterana do Brasil, Brasil

E-mail: natalyssodre@gmail.com

Jussara Alves Pinheiro Sommer

ORCID: https://orcid.org/0000-0002-6485-4828 Universidade Luterana do Brasil, Brasil

E-mail: jussara.sommer@ulbra.br

Eliane Fraga da Silveira

ORCID: https://orcid.org/0000-0002-0992-5136 Universidade Luterana do Brasil, Brasil

E-mail: eliane.silveira@ulbra.br

Nádia Teresinha Schröder

ORCID: https://orcid.org/0000-0001-5505-1137 Universidade Luterana do Brasil, Brasil

E-mail: E-mail: nadia.schroder@ulbra.br

\begin{abstract}
Objective: To analyze the reported cases and the prevalence of schistosomiasis in Brazil, from 2007 to 2017. Methodology: This is an ecological study, using the Database of the Disease and Notification Information System (SINAN) and the Brazilian Institute of Geography and Statistics (IBGE). The variables sex, age group, race/color and education per region and year of notification were selected. Furthermore, the prevalence of each variable was calculated, per 100000 inhabitants, in order to perform the Prais-Winsten regression, Generalized Least Squares and Odds Ratio. Results: In total, 144755 cases were reported in non-endemic areas of Brazil, from 2007 to 2017 . Most records were found in the Southeast $(n=96411)$ and Northeast $(n=45774)$ regions; in males $(n=87$ 149); adults aged 20 to 39 years $(n=58347)$; brown $(n=71843)$; and incomplete 1 st to 4 th grade $(n=23060)$. The trends showed a decline in the analyzed variables, except for the regions of notification and education. As for the odds ratio, the categories female gender, age group from 20 to 39 years old, brown color/race and level of education from the 5th to the 8th grade were identified as vulnerable to the disease. Conclusions: The analyzes showed that the schistosomiasis scenario in Brazil is still a concern, and that improvements are needed in towards public policies and disease control in non-endemic areas.
\end{abstract}

Keywords: Schistosoma mansoni; Public health; Neglected diseases.

\section{Resumo}

Objetivo: Analisar os casos notificados e a prevalência de esquistossomose no Brasil, no período de 2007 a 2017. Metodologia: Trata-se de um estudo ecológico, utilizando o banco de dados do Sistema de Informações de Agravo e Notificação (SINAN) e Instituto Brasileiro de Geografia e Estatística (IBGE). Foram selecionadas as variáveis sexo, faixa etária, raça/cor e escolaridade por região e ano de notificação. Ainda, calculou-se a prevalência de cada variável, por 100 mil habitantes, para analisar a regressão de Prais-Winsten, Mínimos Quadrados Generalizados e Odds Ratio. Resultados: No total, foram notificados 144.755 casos em áreas não endêmicas do Brasil, de 2007 a 2017. Os registros foram majoritariamente das regiões Sudeste $(\mathrm{n}=96.411)$ e Nordeste $(\mathrm{n}=45.774)$; de homens $(\mathrm{n}=87.149)$; adultos de 20 a $39 \operatorname{anos}(\mathrm{n}=58.347)$; pardos $(\mathrm{n}=71.843)$; e $1^{\mathrm{a}}$ à $4^{\mathrm{a}}$ série incompleta $(\mathrm{n}=23.060)$. As tendências mostraram declínio nas variáveis analisadas, exceto para as regiões de notificação e escolaridade. Quanto à razão de chances, as categorias sexo feminino, faixa etária de 20 a 39 anos, cor/raça parda e escolaridade de $5^{\text {a a }} 8^{\text {a }}$ série foram identificadas como vulneráveis à doença. Conclusão: As análises demonstraram que o cenário da esquistossomose no Brasil ainda é preocupante, e que são necessárias melhorias no direcionamento das políticas públicas e controle da doença em áreas não endêmicas.

Palavras-chave: Schistosoma mansoni; Saúde pública; Doenças negligenciadas. 


\begin{abstract}
Resumen
Objetivo: Analizar los casos reportados y la prevalencia de esquistosomiasis en Brasil, de 2007 a 2017. Metodología: Se trata de un estudio ecológico, utilizando la base de datos del Sistema de Información de Enfermedades y Notificación (SINAN) y el Instituto Brasileño de Geografía y Estadística (IBGE). Se seleccionaron las variables sexo, grupo de edad, raza/color y educación por región y año de notificación. Además, se calculó la prevalencia de cada variable, por 100.000 habitantes, para analizar la regresión de Prais-Winsten, Mínimos Cuadrados Generalizados y Odds Ratio. Resultados: En total, se notificaron 144.755 casos en áreas no endémicas de Brasil, de 2007 a 2017. Los registros fueron en su mayoría de las regiones Sudeste $(n=96.411)$ y Noreste $(n=45.774)$; de los hombres $(n=87.149)$; adultos de 20 a 39 años $(n=58.347)$; pardos $(n=71.843)$; y $1^{\circ}$ a $4^{\circ}$ grado incompleto $(n=23.060)$. Las tendencias mostraron una disminución en las variables analizadas, a excepción de las regiones de notificación y educación. En cuanto a la razón de probabilidades, las categorías sexo femenino, grupo de edad de 20 a 39 años, color/raza y educación de $5^{\circ}$ a $8^{\circ}$ grado fueron identificadas como vulnerables a la enfermedad. Conclusión: Los análisis mostraron que el escenario de la esquistosomiasis en Brasil sigue siendo preocupante y que se necesitan mejoras en la dirección de las políticas públicas y el control de enfermedades en áreas no endémicas.
\end{abstract}

Palabras clave: Schistosoma mansoni; Salud pública; Enfermedades desatendidas.

\title{
1. Introduction
}

Schistosomiasis is a parasitic disease of endemic character that occur in 78 countries in the regions of Africa, America, Eastern Mediterranean, Southeast Asia and Western Pacific (World Health Organization [WHO], 2021). Worldwide, it is estimated that a total of 236636204 individuals are infected with helminthiasis and need preventive treatment (WHO, 2021). This pathology causes a great negative impact on public health, as it registers approximately 200 thousand deaths per year and, therefore, it is considered the second most important parasitic infection, only behind malaria (Rocha et al., 2016).

Brazil reports the highest number of patients with Schistosoma mansoni among all American countries, affecting approximately 1,5 million people throughout the national territory (Silva Brito et al., 2020). The geographic distribution of schistosomiasis mansoni in Brazilian states is not homogeneous, even in endemic cities. From the 27 federation units, this parasitosis occurs in 18 of these and in the Federal District (Nascimento et al., 2019). The highest prevalence of the disease occurs in the Southeast region, in the state of Minas Gerais; and in the Northeast region, in the states of Alagoas, Bahia, Ceará, Maranhão, Paraíba, Pernambuco, Piauí, Rio Grande do Norte and Sergipe (Katz, 2018).

Ordinance No. 1 271, of June 6, 2014, of the Ministry of Health, which defines the National List of Compulsory Notification of diseases, injuries and public health events, places mandatory communication on the occurrence of suspected or confirmed schistosomiasis weekly (Brasil, 2014). Thus, cases notified in non-endemic, but vulnerable, unaffected or focus areas, are registered by the Notifiable Diseases Information System (SINAN) (Brasil, 2019). In endemic areas, the Information System of the Schistosomiasis Surveillance and Control Program (SISPCE) is used for coproscopic, epidemiological and malacology surveys (Brasil, 2019).

The occurrence of schistosomiasis is multifactorial and intrinsically associated with favorable environmental conditions for the development of the intermediate host (Biomphalaria spp.) and with the socioeconomic and cultural structure of the resident population (Rodrigues et al., 2019; Sampaio et al., 2017). Public policies in each region can also influence the prevalence of the disease. These factors, when combined, put the local population at risk and promote the maintenance of the parasite's biological cycle, increasing its dispersion (Sampaio et al., 2017). Transmission to humans occurs in locations with precarious and inadequate sanitation conditions, whose population needs these services for domestic and work activities (Saucha et al., 2015).

Despite advances in health services coverage and new diagnostic technologies in Brazil, schistosomiasis still represents a public health concern in the country (Tibiriçá et al., 2011; Silva Brito et al., 2020). The surveillance and control of the disease, along with the decentralization process of epidemiological actions, allowed municipalities to overcome the diagnosis-treatment binomial of schistosomiasis (Silva Brito et al., 2020). However, successive re-emergences occur due to 
migratory movements, expansion of agricultural frontiers and urbanization (Tibiriçá et al., 2011).

In 2012, with the implementation of the Integrated Strategic Actions Plan for Neglected Tropical Diseases (NTDs), public commitments were made to eliminate or reduce the burden of schistosomiasis (Brasil, 2013). The main strategies are based on treating the community residing in the highest risk areas. The United Nations (UN), in its third sustainable development goal, also sets a goal of eliminating epidemics of waterborne diseases, including schistosomiasis (Organização das Nações Unidas [ONU], 2021).

For an effective control, the classification of endemic and non-endemic areas pathology areas must be used as a prerequisite (Katz, 2018). Thus, it is possible to encourage new methodologies for dealing with schistosomiasis, according to each location, to reduce positivity and transmission. In this sense, promote health education and encourage community participation in the disease eradication, since it is preventable and treatable. This study aims to analyze the epidemiological situation of schistosomiasis mansoni reported cases in Brazilian regions, from 2007 to 2017.

\section{Methodology}

An ecological, descriptive and analytical study was conducted on cases of schistosomiasis in Brazil, from 2007 to 2017. The data come from the Information Technology Department of the Unified Health System of the Ministry of Health (DATASUS), through of the Notification and Information System (SINAN). From the database, the sociodemographic variables of sex, age, color/race and education were selected by region and year of disease notification. As for the resident population, estimates were sought from the Brazilian Institute of Geography and Statistics (IBGE).

Schistosomiasis prevalence was calculated according to the Region of Notification, and also for the selected variables, using the following equation: $\mathrm{P}=$ Number of cases of schistosomiasis in a period/Total number of people residing in the same period*100 000 .

Prais-Winsten regression by variable was applied to understand whether the disease exhibited trends of growth, decline or stability over the years. The calculation was based on the study by Antunes (2005) and applied by Böhm, Costa, Neves, Flores and Nunes (2016), who calculated the Annual Increment Rate (AIR) from the regression data: AIR= [$1+(10 \mathrm{~b})]^{*} 100$, where $\mathrm{b}$ is the slope coefficient of the straight line in the Prais-Winsten regression. Trends were considered significant when the regression $\mathrm{p}$ values were alpha $<0.05$. Otherwise, they were classified as stable.

Generalized Least Squares (GLS) regression was applied to understand the dynamics between schistosomiasis and the variables over the years. For this, the auto-regressive model of moving averages (ARMA) was used as a precept of correlation. For the variables education, age, sex and color/race, the Odds Ratio and the Confidence Interval (95\% CI), with Lower Limit (LL) and Upper Limit (UL), were also calculated, in which the reference categories were selected by population number or vulnerability to the disease.

Data were tabulated in Microsoft Office Excel 2007 and analyzed using SPSS version 13, PAST 4.07 and R Project software. In this last statistical program, the analysis was developed using the nlme package and the gls function. The following model was elaborated: $\operatorname{gls}(\mathrm{y} \sim \mathrm{x}$, data=data.df,correlation=corARMA( $\mathrm{p}=1, \mathrm{q}=0$, form= $\mathrm{t})$, method="ML"), where $\mathrm{y}$ is the prevalence and $\mathrm{x}$ the predictor variables. Furthermore, a spatial analysis of prevalence was carried out using an Open Source Geographic Information System (GIS), QGIS 3.16.

\section{Results}

Through the survey for schistosomiasis mansoni notifications in Brazil, from 2007 to 2017, we confirmed 144755 positive cases. Of this total, $66.6 \%$ occurred only in the Southeast region and $31.6 \%$ in the Northeast region. The remaining 
29.8\% were divided between South, North and Midwest, respectively (Table 1).

When analyzing the records by year, we found that 2007 was the most critical year regarding the number of confirmed cases and prevalence of the historical series (Figure 1). In that year, schistosomiasis was predominant in the Northeast, but markedly decreased in 2008. In the following year, the number of notifications in the Southeast doubled. The region reached its peak in 2010, with a prevalence of 30.7/100 000 inhabitants. In the following years, the number of infected consecutively decreases until 2017. The South region exhibited the same trend as the Northeast, with 2007 representing the worst scenario in the series, however, reaching a low prevalence of 1.15/100 000 inhab. In 2009, positive cases increased again, followed by fluctuations between 77 to 40 notifications over the next eight years. The disease was also expressive in 2007 for the Midwest region, however, the years 2013 and 2016 also showed the same value. The North showed a different scenario than the other regions, where 2009 and 2017 were the years with the highest number of notifications.

Table 1. Number of Schistosomiasis cases in the analyzed series, 2007-2017.

\begin{tabular}{|c|c|c|c|c|c|c|}
\hline Notification Region & North & Northeast & Southeast & South & Midwest & Total \\
\hline 2007 & 62 & 26603 & 6155 & 314 & 69 & 33203 \\
\hline 2008 & 83 & 5742 & 7344 & 177 & 40 & 13386 \\
\hline 2009 & 110 & 2605 & 15532 & 273 & 43 & 18563 \\
\hline 2010 & 80 & 1582 & 25224 & 77 & 36 & 26999 \\
\hline 2011 & 46 & 1525 & 13771 & 49 & 65 & 15456 \\
\hline 2012 & 33 & 1318 & 6921 & 61 & 34 & 8367 \\
\hline 2013 & 42 & 1185 & 5098 & 40 & 69 & 6434 \\
\hline 2014 & 70 & 1419 & 4863 & 51 & 63 & 6466 \\
\hline 2015 & 59 & 1483 & 4733 & 43 & 64 & 6382 \\
\hline 2016 & 64 & 1092 & 3859 & 56 & 69 & 5140 \\
\hline 2017 & 100 & 1220 & 2911 & 62 & 66 & 4359 \\
\hline Total & 749 & 45774 & 96411 & 1203 & 618 & 144,755 \\
\hline
\end{tabular}

Source: SINAN (2021). 
Figure 1. Prevalence of Schistosomiasis Mansoni by Notification Region, from 2007 to 2017.
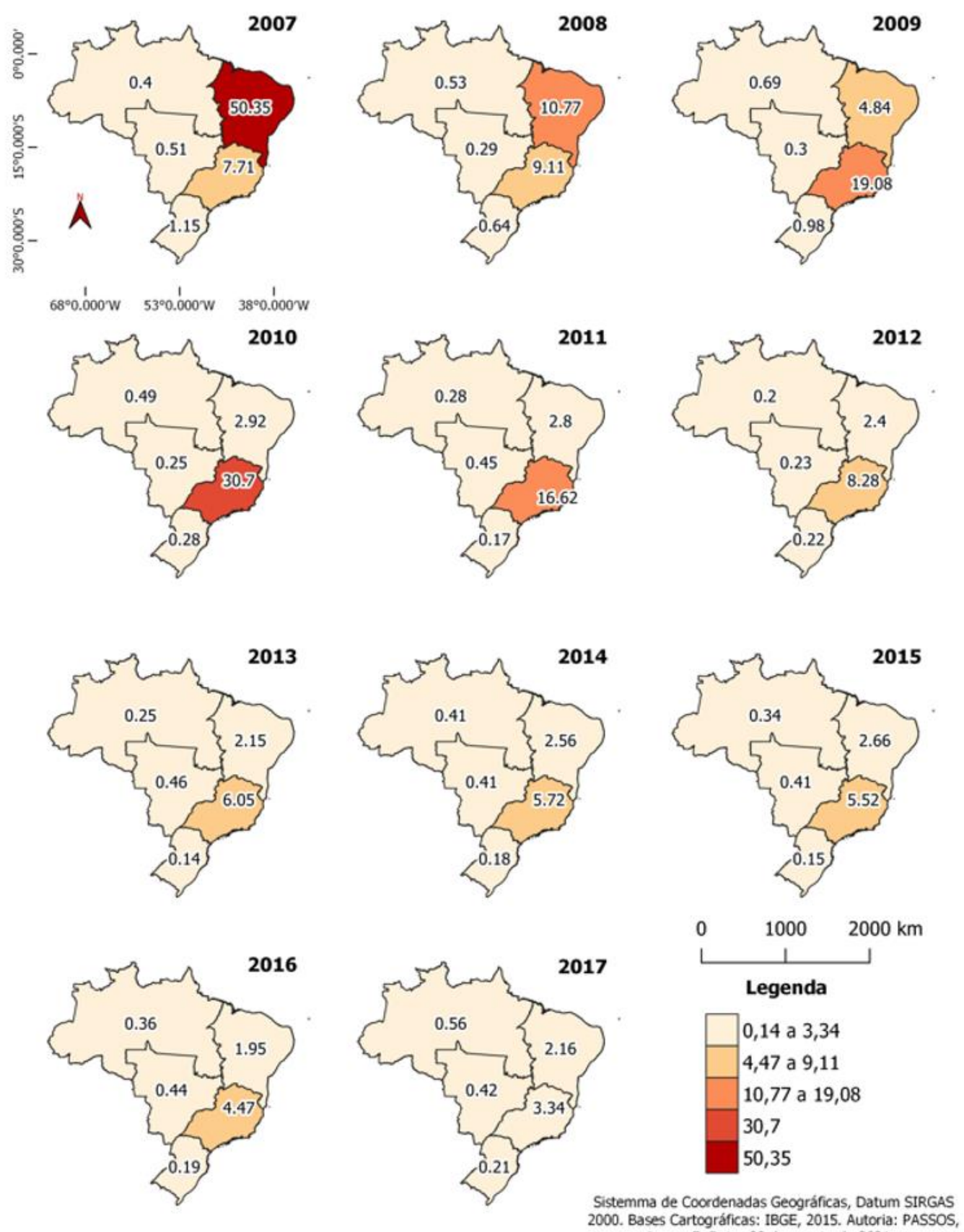
Luana F. Data: 29 de agosto de 2021

Source: SINAN (2021).

Regarding gender, we found that $60.2 \%(\mathrm{n}=87$ 1490) of the infected population was male (Table 2). As for the age group, the population between 20 and 39 years old concentrated the highest number of infected people ( $\mathrm{n}=58347)$, mainly in the Southeast. Data show that the disease affects, to a greater extent, people from the Southeast and Northeast between the ages 10 and 59 years old. We observed that in the age group under nine and over 60, the Southeast and Northeast regions express high values compared to other locations.

In the analysis of the color/race variable, a self-declared option by those who tested positive for schistosomiasis, it was observed that brown individuals $(n=71843)$ were predominant among other infected groups. In the Northeast, Midwest and North regions, the brown population includes more than half of the parasitized people, with percentages of $59.3 \%, 58.7 \%$ and $54.9 \%$ respectively. In the total series, 858 indigenous people were diagnosed with the disease, with a proportion of $0.8 \%$ 
(North), 0.6\% (Northeast, Southeast and Midwest) and 0.4\% (South). The number of ignored/whites stands out, with a record of 22414 cases without identification of self-declaration of color/race. In this situation, the Southeast region has the highest percentage $(16.1 \%)$.

In relation to education level of the population infected with schistosomiasis, a pattern of notified cases and level of schooling in elementary, secondary and higher education levels is identified. Regarding the predominance in the Brazilian regions, the Southeast $(n=93$ 144) and Northeast $(n=44284)$ stand out. In these regions, the proportion of ignored/whites reaches around 37\%, while for the North and Center-West, these percentages are also high, with $27.6 \%$ and $27.1 \%$ respectively. Separately, the levels of incomplete 1st to 4th grade and incomplete 5th to 8th grade showed higher percentages in the North, Northeast, Southeast and Midwest, while the South region was higher for the 4th complete grade.

Table 2. Occurrence of Schistosomiasis according to sex, age group, color/race, education level and Reporting Region, 20072017.

\begin{tabular}{|c|c|c|c|c|c|}
\hline \multirow{2}{*}{ Variables } & North & Northeast & Southeast & South & Midwest \\
\hline & n $(\%)$ & n $(\%)$ & n $(\%)$ & n $(\%)$ & n $(\%)$ \\
\hline \multicolumn{6}{|l|}{ Sex/Gender } \\
\hline Female & $312(41.7)$ & $20439(35.4)$ & $36184(34.3)$ & $371(30.8)$ & $279(45.1)$ \\
\hline Male & $437(58.3)$ & 25323 (43.8) & $60218(57.1)$ & $832(69.2)$ & $339(54.9)$ \\
\hline Ignored & $0(0.0)$ & $12(20.8)$ & $9(8.5)$ & $0(0.0)$ & $0(0.0)$ \\
\hline \multicolumn{6}{|l|}{ Age group } \\
\hline 0 a 09 & $30(4.0)$ & $3269(6.1)$ & 6998 (5.9) & $90(7.5)$ & $30(4.9)$ \\
\hline 10 a 19 & 57 (7.6) & 9809 (18.2) & 20453 (17.3) & 287 (23.9) & $98(15.9)$ \\
\hline 20 a 39 & $273(36.4)$ & 18407 (34.2) & $38831(32.8)$ & $531(44.1)$ & 305 (49.4) \\
\hline 40 a 59 & $290(38.7)$ & 10073 (18.7) & 22868 (19.3) & $222(18.5)$ & $135(21.8)$ \\
\hline$>60$ & 99 (13.2) & 4206 (7.8) & $7239(6.1)$ & $73(6.1)$ & $50(8.1)$ \\
\hline Ignored & $0(0.0)$ & 8 (14.9) & $22(18.6)$ & $0(0.0)$ & $0(0.0)$ \\
\hline \multicolumn{6}{|l|}{ Color/race } \\
\hline White & $225(30.0)$ & $5891(12.9)$ & $26848(27.8)$ & $722(60.0)$ & 117 (18.9) \\
\hline Black & 59 (7.9) & 5207 (11.4) & 8308 (8.6) & $134(11.1)$ & $56(9.1)$ \\
\hline Yellow & $8(1.1)$ & $542(1.2)$ & 1504 (1.6) & $9(0.7)$ & $10(1.62)$ \\
\hline Brown & $411(54.9)$ & $27133(59.3)$ & $43629(45.3)$ & 307 (25.5) & $363(58.7)$ \\
\hline Indigenous & $6(0.8)$ & $271(0.6)$ & $572(0.6)$ & $5(0.4)$ & $4(0.6)$ \\
\hline Ignored & $40(5.3)$ & $6730(14.7)$ & $15550(16.1)$ & $26(2.2)$ & $68(11.0)$ \\
\hline \multicolumn{6}{|l|}{ Education level } \\
\hline Illiterate & $65(8.9)$ & $2.142(4.8)$ & 2687 (2.9) & $34(2.9)$ & $16(2.7)$ \\
\hline 1 st to 4 th grade incomplete & $142(19.5)$ & $7393(16.7)$ & $15252(16.4)$ & $180(15.4)$ & $93(15.6)$ \\
\hline 4th grade complete & 85 (11.7) & $4639(10.5)$ & $6918(7.4)$ & $305(26.2)$ & $43(7.2)$ \\
\hline 5th to 8th grade incomplete & $89(12.2)$ & $7083(16.0)$ & $14844(15.9)$ & $230(19.7)$ & $115(19.3)$ \\
\hline Complete primary education & $41(5.6)$ & $2309(5.2)$ & $5055(5.4)$ & $84(7.2)$ & $43(7.2)$ \\
\hline Incomplete high school & $30(4.1)$ & $1866(4.2)$ & $5053(5.4)$ & 77 (6.6) & $46(7.7)$ \\
\hline Complete high school & $43(5.9)$ & $1904(4.3)$ & $7242(7.8)$ & $114(9.8)$ & $58(9.7)$ \\
\hline Incomplete higher education & $6(0.8)$ & $155(0.4)$ & $537(0.6)$ & $12(1.0)$ & $6(1.0)$ \\
\hline Complete higher education & $26(3.6)$ & $350(0.8)$ & $1.079(1.2)$ & $10(0.9)$ & $15(2.5)$ \\
\hline Ignored & $201(27.6)$ & $16443(37.1)$ & $34477(37.0)$ & $120(10.3)$ & $162(27.1)$ \\
\hline
\end{tabular}

Source: SINAN (2021).

The Annual Increment Rate (AIR) indicated a stable trend for the prevalence of schistosomiasis mansoni in Brazil (Table 3). In the regions of notification, only the Northeast and South showed a decline. For the variables sex, age and color/race, there was a tendency to decline over the years. Regarding education, only the higher education class, incomplete or 
complete, showed stability in terms of prevalence, as all others showed a decline.

Table 3. Status of Schistosomiasis prevalence by Notification Region and variables sex, age, color/race and education, 20072017.

\begin{tabular}{|c|c|c|c|}
\hline Epidemiological variables & Annual Increment Rate (AIR) & p-value & Status \\
\hline \multicolumn{4}{|l|}{ Region of notification } \\
\hline North & 0.002 & 0.4874 & Stable \\
\hline Northeast & -0.998 & 0.0001 & Decrease \\
\hline Southeast & -0.899 & 0.1024 & Stable \\
\hline South & -0.177 & 0.0021 & Decrease \\
\hline Midwest & 0.024 & 0.4386 & Stable \\
\hline Brazil & -0.604 & 0.2194 & Stable \\
\hline \multicolumn{4}{|l|}{ Sex/Gender } \\
\hline Male & -0.8216 & 0.0005 & Decrease \\
\hline Female & -0.6970 & 0.0009 & Decrease \\
\hline \multicolumn{4}{|l|}{ Age group } \\
\hline 0 to 9 & -0.217 & 0.004 & Decrease \\
\hline 10 to 19 & -0.533 & 0.001 & Decrease \\
\hline 20 to 39 & -0.713 & 0.000 & Decrease \\
\hline 40 to 59 & -0.408 & 0.002 & Decrease \\
\hline$>60$ & -0.124 & 0.009 & Decrease \\
\hline \multicolumn{4}{|l|}{ Color/Race } \\
\hline Ignored/White & -0.3854 & 0.0026 & Decrease \\
\hline White & -0.4413 & 0.0006 & Decrease \\
\hline Black & -0.2578 & 0.0003 & Decrease \\
\hline Yellow & -0.0438 & 0.0008 & Decrease \\
\hline Brown & -0.7716 & 0.0014 & Decrease \\
\hline Indigenous & -0.0208 & 0.0011 & Decrease \\
\hline \multicolumn{4}{|l|}{ Education } \\
\hline Ignored/White & -0.618 & 0.004 & Decrease \\
\hline Illiterate & -0.094 & 0.001 & Decrease \\
\hline 1 st to 4 th grade incomplete & -0.405 & 0.002 & Decrease \\
\hline 4th grade complete & -0.265 & 0.000 & Decrease \\
\hline 5th to 8 th grade incomplete & -0.408 & 0.000 & Decrease \\
\hline Complete primary education & -0.148 & 0.000 & Decrease \\
\hline Incomplete high school & -0.114 & 0.001 & Decrease \\
\hline Complete high school & -0.115 & 0.003 & Decrease \\
\hline Incomplete higher education & -0.004 & 0.147 & Stable \\
\hline Complete higher education & -0.000 & 0.948 & Stable \\
\hline
\end{tabular}

Legend: Values in bold represent alpha $<0.05$. Source: Authors.

Regarding comparisons among regions, the analysis showed significant differences in the disease prevalence across the country. Using the Southeast as a reference category, due to the greater number of populations, the Midwest, North and South regions were statistically different, showing the lowest values for parasitosis (Table 4).

When the female group is used as a reference, the analysis shows statistical differences between sex/genders. Thus, female individuals exhibit an extremely higher prevalence compared to those identified as males. In age group variable, it is obtained that only those infected from 20 to 39 years old were statistically different. This interval has a prevalence 10.70 times higher than the reference category of 0 to 9 years. For color/race, there were statistical differences between the yellow and brown categories. The yellow group is less likely to contract the disease, while the brown group is 7.05 times more likely. 
When using the illiterate category as a reference for education, it was shown that only the 5th to 8th grade was statistically different. In these series, the prevalence is 2.34 times higher. The other categories of this variable did not differ from the reference group.

Table 4. Comparison of prevalence between the variables region of notification, sex, age, color/race and education, and odds ratio, 2007-2017.

\begin{tabular}{|c|c|c|c|c|c|c|c|}
\hline Sociodemographic variables & Statistics & Standar Error & T value & p-value & $\begin{array}{l}\text { Odds } \\
\text { Ratio } \\
\end{array}$ & $95 \%$ CI LL & 95\% CI UL \\
\hline \multicolumn{8}{|l|}{ Region of Notification } \\
\hline Southeast & \multicolumn{4}{|c|}{ Reference category } & - & - & - \\
\hline Midwest & -10.005 & 4.774 & -2.096 & 0.041 & - & - & - \\
\hline Northeast & -0.711 & 4.522 & 0.157 & 0.876 & - & - & - \\
\hline North & -13.986 & 4.774 & -2.929 & 0.005 & - & - & - \\
\hline South & -9.361 & 4.522 & -2.070 & 0.044 & - & - & - \\
\hline \multicolumn{8}{|l|}{ Sex/Gender } \\
\hline Female & \multicolumn{4}{|c|}{ Reference category } & 1178.312 & 0.199 & 6988473 \\
\hline Male & -5.367 & 2.297 & -2.336 & 0.030 & 0.005 & 0 & 0.42 \\
\hline \multicolumn{8}{|l|}{ Age group } \\
\hline 0 to 9 & \multicolumn{4}{|c|}{ Reference category } & 1.47 & 0.59 & 3.63 \\
\hline 10 to 19 & 0.927 & 0.641 & 1.447 & 0.154 & 2.53 & 0.72 & 8.88 \\
\hline 20 to 39 & 2.370 & 0.652 & 3.634 & 0.001 & 10.70 & 2.98 & 38.39 \\
\hline 40 to 59 & 1.251 & 0.652 & 1.918 & 0.061 & 3.50 & 0.97 & 12.56 \\
\hline$>60$ & 0.199 & 0.654 & 0.305 & 0.762 & 1.22 & 0.34 & 4.40 \\
\hline \multicolumn{8}{|l|}{ Color/race } \\
\hline White & \multicolumn{4}{|c|}{ Reference category } & 4.77 & 1.74 & 13.06 \\
\hline Black & -0.841 & 0.702 & -1.197 & 0.236 & 0.43 & 0.11 & 1.71 \\
\hline Yellow & -1.798 & 0.725 & -2.480 & 0.016 & 0.17 & 0.04 & 0.69 \\
\hline Brown & 1.953 & 0.726 & 2.689 & 0.009 & 7.05 & 1.70 & 29.27 \\
\hline Indigenous & -1.345 & 0.730 & -1.843 & 0.070 & 0.26 & 0.06 & 1.09 \\
\hline Ignored/White & -0.630 & 0.705 & -0.894 & 0.375 & 0.53 & 0.13 & 2.12 \\
\hline \multicolumn{8}{|l|}{ Education } \\
\hline Illiterate & \multicolumn{4}{|c|}{ Reference category } & 1.27 & 0.70 & 2.32 \\
\hline 1st to 4 th grade incomplete & 0.783 & 0.417 & 1.880 & 0.063 & 2.19 & 0.97 & 4.95 \\
\hline 4th grade complete & 0.294 & 0.431 & 0.684 & 0.496 & 1.34 & 0.58 & 3.12 \\
\hline 5th to 8 th grade incomplete & 0.850 & 0.432 & 1.969 & 0.052 & 2.34 & 1.00 & 5.45 \\
\hline Complete primary education & 0.176 & 0.432 & 0.408 & 0.684 & 1.19 & 0.51 & 2.78 \\
\hline Incomplete high school & 0.090 & 0.432 & 0.207 & 0.836 & 1.09 & 0.47 & 2.55 \\
\hline Complete high school & 0.212 & 0.432 & 0.491 & 0.625 & 1.24 & 0.53 & 2.88 \\
\hline Incomplete higher education & -0.193 & 0.432 & -0.446 & 0.657 & 0.83 & 0.35 & 1.92 \\
\hline Complete higher education & -0.173 & 0.434 & -0.398 & 0.691 & 0.84 & 0.36 & 1.97 \\
\hline Ignored & 2.148 & 0.419 & 5.131 & 0.000 & 8.57 & 3.77 & 19.47 \\
\hline
\end{tabular}

Legend: Values in bold represent alpha $<0.05$; LL - Lower limit; UL - Upper Limit. Source: Authors.

\section{Discussion}

The introduction of schistosomiasis mansoni in Brazilian territory was addressed by Ministry of Health (Brasil, 2014). The disease was initially established in the Northeast, through the African slave trade, and migratory flows were responsible for the parasite spread to other regions of the country (Brasil, 2014). For Barreto and Lobo (2021), the Northeast has ideal natural and artificial water collections for the development of vector molluscs. In addition, its Municipal Human Development Index (MHDI), based on the dimensions of longevity, education and income, is below the national average, as discussed by 
Martins, Cury Pontes and Higa (2018). The combination of these factors may justify the higher prevalence of schistosomiasis found in the region in the first years of the historical series of this study.

In contrast, the findings of this research show that the prevalence of schistosomiasis in the Northeast is declining, showing a decrease in reported cases since 2007, losing its position as the area with the highest transmission to the Southeast. This reduction may result from improvements in life quality in the Northeast region, as the MHDI is changed to medium development since 2010, and greater disease treatment coverage (Martins et al., 2018; Nascimento \& Meirelles, 2020). However, when using data related to passive surveillance, the number of cases is lost in some regions, as only non-endemic areas are covered by SINAN (Brasil, 2019). Actions for the prevention and control of the endemic cannot be discarded in the absence of disease registration on the platform (Brasil, 2014). The platform has data up to 2017, and this was the main limitation found in the study, since the lack of information prevents analyzing the current trend of the disease.

Souza et al. (2020) point out that schistosomiasis has a geographic transition pattern in Brazil, due to urbanization and conditions that contribute to the biological cycle of the parasite. Thus, even in non-endemic areas, the Southeast showed stability of notifications over the years. For Costa and Silva Filho (2021), the region presents heterogeneity of cases due to its distinct physical, environmental and social characteristics. Clinical diagnosis is the main difficulty found in these non-endemic areas (Vitorino et al., 2012).

The predominance of males in the number of reported schistosomiasis cases was also observed in other studies (Cardoso et al., 2021; Barreto \& Lobo, 2021). According to Gomes, Galindo, Lima \& Silva (2016), the group has difficulties in accessing health services, such as low demand and incompatible working hours. However, when the odds ratios are analyzed, which consider the resident population of regions, females become more vulnerable to the disease.

According to Sobrinho et al. (2020), the population aged 20 to 59 years are the most affected by schistosomiasis in the Northeast region. Thus, the infection can be directly associated with occupation, as it affects the financially active age group (Sobrinho et al., 2020). This finding corroborates the data found in this study, where the reported cases were mostly composed by people aging 20 to 39 years old. Furthermore, it is notable that the group uses water collections with potential occurrence of the intermediate host for the most varied purposes, such as horticulture (Leal Neto et al., 2012).

Regarding color/race, brown individuals were more infected in the North, Northeast, Southeast and Midwest regions. Rodrigues Junior et al. (2017) evaluated that this variable has no direct influence on pathophysiology. Furthermore, the Brazilian population profile is mostly brown and, therefore, may explain the high number of records for the category (Rodrigues Junior et al., 2017).

Low education was associated with high numbers of cases. This means that the most significant prevalence for the 5th to 8th year incomplete group may demonstrate a lack of knowledge about the disease by the population and higher difficulty in implementing prevention and control strategies (Melo et al., 2011). In this context, it is essential to strengthen health education (Melo et al., 2011). These actions, together with preventive chemotherapy, interventions in socio-environmental areas and effective public policies, contribute to the achievement of established goals and to promote the health and well-being of the Brazilian population.

\section{Conclusion}

The Brazilian territory showed stability in schistosomiasis prevalence during the analyzed period. This condition is concerning in the the Southeast region, which presents the largest population in the country. Some social determinants, such as socioeconomic, cultural and environmental aspects, seem to indicate where the installation and permanence of the disease occur. However, the sociodemographic variables evaluated are, for the most part, declining in terms of prevalence, with possible advances in the parasitosis reduction. 
Based on our results, it is recommended that control actions in non-endemic areas are focused on females, economically active populations, brown individuals and people with incomplete primary education. In this context, this research can contribute to the foundation of public health policies and elucidates the lack of feedback from SINAN regarding schistosomiasis.

\section{References}

Antunes, J. L. F. (2005). Mortalidade por câncer e desigualdade social em São Paulo (Tese). Universidade de São Paulo, São Paulo, Brasil.

Barreto, B. L. \& Lobo, C. G. (2021). Aspectos epidemiológicos e distribuição de casos de esquistossomose no Nordeste brasileiro no período de 2010 a 2017. Revista Enfermagem Contemporânea, 10(1), 111-118.

Böhm, A. W., Costa, C. S., Neves, R. G., Flores, T. R. \& Nunes, B. P. (2016). Tendência da incidência de dengue no Brasil, 2002-2012. Epidemiologia e Serviços de Saúde, 25(4), 725-733.

Brasil. (2013). Ministério da Saúde. Secretaria de Vigilância em Saúde. Departamento de Vigilância das Doenças Transmissíveis. Plano integrado de ações estratégicas de eliminação da hanseníase, filariose, esquistossomose e oncocercose como problema de saúde pública, tracoma como causa de cegueira e controle das geohelmintíases: plano de ação 2011-2015 (1a ed., 1a reimpr.). Brasília, DF: Ministério da Saúde.

Brasil. (2014). Ministério da Saúde. Secretaria de Vigilância em Saúde. Departamento de Vigilância Epidemiológica. Vigilância da Esquistossomose Mansoni: diretrizes técnicas (4a ed.). Brasília, DF: Ministério da Saúde.

Brasil. (2019). Ministério da Saúde. Secretaria de Vigilância em Saúde. Guia de Vigilância Epidemiológica. Ministério da Saúde.

Cardoso, D. M., Araújo, A. F., Gonçalves, S. A., Vasconcellos, G. L., Gonçalves, G. H., Arêdes, F. M. P. \& Leite, P. M. (2021). Aspectos espaciais, sociodemográficos, clínicos e temporais da esquistossomose no estado de Minas Gerais entre os anos de 2011 e 2020. Brazilian Journal of Development, 7(8), 78130-78143.

Costa, J. V. B. \& Silva Filho, J. M. (2021). Esquistossomose mansônica: uma análise do perfil epidemiológico na região sudeste. Revista Saúde.Com, 17(3), 2226-2234.

Gomes, A. C. L., Galindo, J. M., Lima, N. N. \& Silva, É. V. G. (2016). Prevalência e carga parasitária da esquistossomose mansônica antes e depois do tratamento coletivo em Jaboatão dos Guararapes, Pernambuco. Epidemiologia e Serviços de Saúde, 25 (2), $243-250$.

Katz, N. (2018). Inquérito Nacional de Prevalência da Esquistossomose mansoni e Geo-helmintoses. CPqRR.

Leal Neto, O. B., Galvão, T. Y. C., Esteves, F. A. M., Silva Gomes, A. M. A., Gomes, E. C. S., Araújo, K. C. G. M. ... Barbosa, C. S. (2012). Análise espacial dos casos humanos de esquistossomose em uma comunidade horticultora da Zona da Mata de Pernambuco, Brasil. Revista Brasileira de Epidemiologia, 15(4), $771-780$.

Martins, P. C. R., Cury Pontes, E. R. J. \& Higa, L. T. (2018). Convergência entre as Taxas de Mortalidade Infantil e os Índices de Desenvolvimento Humano no Brasil no período de 2000 a 2010. Interações (Campo Grande), 19(2), 291-303.

Melo, A. G. S., Melo, C. M., Oliveira, C. C. C., Oliveira, D. S., Santos, V. B. \& Jeraldo, V. L. S. (2011). Esquistossomose em área de transição rural-urbana: reflexões epidemiológicas. Ciência, Cuidado e Saúde, 10(3), 506-513.

Nascimento, G. L., Pegado, H. M., Domingues, A. L. C., Ximenes, R. A. A., Itria, A., Cruz, L. N. \& Oliveira, M. R. F. (2019). The cost of a disease targeted for elimination in Brazil: the case of schistosomiasis mansoni. Memórias do Instituto Oswaldo Cruz, 114, e180347.

Nascimento, I. M. E. \& Meirelles, L. M. A. (2020). Análise do perfil epidemiológico da esquistossomose no Nordeste do Brasil. Research, Society and Development, 9(11), e58591110022.

Organização das Nações Unidas. (2021). Objetivos de Desenvolvimento Sustentável: Saúde e Bem-estar. https://brasil.un.org/pt-br/sdgs/3

Rocha, T. J. M., Santos, M. C. S., Lima, M. V. M., Calheiros, C. M. L. \& Wanderley, F. S. (2016). Aspectos epidemiológicos e distribuição dos casos de infecção pelo Schistosoma mansoni em municípios do estado de Alagoas, Brasil. Revista Pan-Amazônica de Saúde, 7(2), 27-32.

Rodrigues, W. P., Gonçalves, P. D. \& Santiago, P. S. N. (2019). Fatores de risco e possíveis causas de Esquistossomose na população residente das margens do riacho de canas em Itapicuru - BA. Revista Eletrônica Acervo Saúde, 11(8), e159.

Rodrigues Junior, C. A., Dias, F. C. F., Silva Rosa, R. T. A., Cardoso, C. R. L., Santos Veloso, F. P. F. \& Mariano, S. M. B. (2017). Esquistossomose na região Norte do Brasil. Revista de Patologia do Tocantins, 4(2), 2017.

Sampaio, L. N. N., França, J. K. R., Lima, J. M. S. F. \& Miranda, L. N. (2017). O enfrentamento do paciente e a esquistossomose. Cadernos de graduação Ciências Biológicas e da Saúde, 4(2), 337-348.

Saucha, C. V. V., Silva, J. A. M. \& Amorim, L. B. (2015). Condições de saneamento básico em áreas hiperendêmicas para esquistossomose no estado de Pernambuco em 2012. Epidemiologia e Serviços de Saúde, 24(3), 497-506.

Silva Brito, M. I. B., Silva, M. B. A. \& Quinino, L. R. M. (2020). Situação epidemiológica e controle da esquistossomose em Pernambuco: estudo descritivo, 2010-2016. Epidemiologia e Serviços de Saúde, 29(2), e2019252. 
Research, Society and Development, v. 11, n. 2, e31011225579, 2022

(CC BY 4.0) | ISSN 2525-3409 | DOI: http://dx.doi.org/10.33448/rsd-v11i2.25579

Sobrinho, F. S. L., Silva, M. C. S., Lima, L. L. C., Sobrinho, G. K. L., Lopes, E. A. P. \& Feitosa, A. P. S. (2020). Incidência de Esquistossomose Mansônica no Nordeste brasileiro, no período de 2013 a 2017. Diversitas Journal, 5(4), 2881-2889.

Souza, H. P., Oliveira, W. T. G. H., Santos, J. P. C., Toledo, J. P., Ferreira, I. P. S., Esashika, S. N. G. S. \& Delácio, A. S. (2020). Doenças infecciosas e parasitárias no Brasil de 2010 a 2017: aspectos para vigilância em saúde. Revista Panamericana de Salud. Pública, 44, e. 10.

Tibiriçá, S. H. C., Guimarães, F. B. \& Teixeira, M. T. B. (2011). A esquistossomose mansoni no contexto da política de saúde brasileira. Ciência \& Saúde Coletiva, 16(1), 1375-1381.

Vitorino, R. R., Souza, F. P. C., Costa, A. P., Faria Júnior, F. C., Santana, L. A. \& Gomes A. P. (2012). Esquistossomose mansônica: diagnóstico, tratamento, epidemiologia, profilaxia e controle. Revista da Sociedade Brasileira de Clínica Médica, 10(1), 39-45.

World Health Organization. (2021). Schistosomiasis. https://www.who.int/news-room/fact-sheets/detail/schistosomiasis 